\title{
International Journal of Research in Library Science (IJRLS)
}

ISSN: $2455-104 X$

DOI: $10.26761 /$ IJRLS.7.4.2021.1478

Volume 7, Issue 4 (October-December) 2021, 226-235, Paper ID: IJRLS-1478

Received: 15 November. 2021 ; Accepted: 26 Nov. 2021 ; Published: 29 November. 2021

Copyright $\Subset 2021$ Author(s) retain the copyright of this article. This article is published under the terms of the Creative Commons Attribution License 4.0

\section{Human Relations in Academic Libraries as Predictor in Managing the Spread of COVID-19 Pandemic for Sustainable Economic Development in Nigeria}

\author{
Abiola Abosede Sokoya'; ${ }^{1}$ Lukmon Abolaji George²; \\ George O. Onyenania ${ }^{3}$
}

\author{
Yaba College of Technology, Library, Yaba-Lagos ${ }^{1,2,3}$ \\ aasokoya@yahoo.co.uk, george_bolaji@yahoo.com, onyenaniageorge@yahoo.com
}

\begin{abstract}
In organizations, which academic library is one of them, human relations $(H R)$ are sine-qua-non for growth and development. HR is being used by successful organizations all over the world not only to grow their businesses, but also to make a big impact on the economy of their countries. Libraries are critical to a country's economic recovery and progress, particularly in difficult times like the current COVID-19 Pandemic sweeping the globe. Thus, the study looks into HR in academic libraries as a predictor in preventing the spread of the virus in Lagos State to enhance and sustain long-term economic development. The population includes all categories of library users at UNILAG, YABATECH and FCE. Slovin's algorithm for sample size determination was used to pick a sample size of 384 respondents using the multivariate random sampling technique. Data was gathered via a questionnaire. To address the study research questions, the whole data obtained from 351 respondents was analyzed using descriptive and inferential statistics. The most important findings are: HR activities in academic libraries' influence on the spread of COVID-19 in the country are low, while the level of management of COVID-19 in the country is relatively poor. Several problems were discovered to confront library users in the utilization of library resources toward the management of COVID-19, and recommendations were provided. The study also indicates that HR concept is a significant variable in library services that could affect users' attitudes toward library resource use, allowing for more effective management of the deadly virus's spread in the country would go a long way in attaining sustainable national development among others.
\end{abstract}

KEYWORDS: Human Relations, Library Services, Users, Covid-19 Pandemic and Economic Development. 


\section{Human Relations in Academic Libraries as Predictor in Managing the Spread of COVID-19 Pandemic for Sustainable Economic Development in Nigeria}

\section{INTRODUCTION}

Organizational growth and development are dependent on human relations (HR).

Human relations are being used by successful companies and institutions all around the world to grow their organizations and institutions, as well as to advance their country's overall economic system. Access to precise and reliable data is essential for national economic development and prosperity. In this regard, libraries perform crucial roles, particularly in tough times like the present. The globe is being ravaged by the COVID-19 Pandemic. COVID19, also known as the corona-virus, has been threatening the human race and existence in a variety of ways, including the social-economic lives of people all over the world, with signs of wreaking havoc on the global economic system and its long-term viability.

Sustainable economic development is a broad word that refers to all types of growth that meets the economic needs of current generations while not jeopardizing future generations (Giraldo, 2019). It is "investment in commercial, social, constructed, and ecological environments that promotes increased prosperity for everybody, now and in the future" (International Economic Development Council, 2017); or employing the five aspects of Water, Energy, Waste, Ecology, and Food to make a breakthrough in merging profit with sustainable objectives. Micro farming, solar energy expansion, air to water innovations, universal works of recycling, and sustainable fish farming are among the elements (Giraldo, 2019). A multi-dimensional process including the change and improvement of a nation's or country's economic and social-political problems is known as sustainable economic development (Okemakinde, 2014).

Access to quality information is critical to the growth and development of any nation's economic system, as outlined above. There is little doubt that the volume and quality of information available to a nation's citizens or at its disposal determines the quality of its health system and overall economic architecture.

Thus, it has long been highlighted in extant literature that a man's, an organization's, or a nation's greatness is no longer dependent on the amount of wealth or natural endowment they have, neither the amount of money it has, but by the amount of information or expertise he or she possesses. The widespread misconception among Nigerians about the existence or non-existence of COVID-19, as well as the resulting lack of readiness to undergo COVID-19 testing and treatment, as well as the resulting effects on the spread of management problems, portends danger to lives and the country's entire economic system.

Indeed, poor/non-compliance with the use of face/nose masks/shields, or regular hand washing in running water/use of hand sanitizers, as well as social-distancing among others as guidelines provided by the NCDC - Nigeria Centre for Disease Control) reported in most media across the country and beyond are signs of poor hygiene, and a lack of quality/reliable information occasioned by poor human relations among Nigerians, despite the fact that quality/reliable information is at the heart of the existence and construction of libraries around the world. As a result, access to quality information and distribution is critical to overcoming the possible hazards and threat of COVID-19 to our nation's economic growth and development. In terms of statutory and professional gathering/collection and management of verified information resources, such information is usually and dependably resident or available in libraries. In order for such information resources to be put to good use, it is necessary that their availability be made known to users by those who are involved in human relations practices in libraries. 
The systematic study and use of knowledge about how individuals and groups function inside the organizations where they work is characterized as human relations (HR) (Anonymous Publisher, 2012). Human interactions encompass a wide range of activities including individuals, social groups, and organizations.

In fact, human relations are all about individuals, particularly those at work who make their workplaces run well. HR allows corporate human assets to discuss their relationship-building tactics for interacting with the organization's market and colleagues (Dankowski, 2018).Social contacts and networking are at the heart of human relations.

There are a number of methods that librarians and libraries can successfully promote social interaction and foster a collaborative, collegial environment that could aid in the fight against the COVID-19 epidemic, which is endangering the entire world's human social-economic system. Human relations practices are a critical component of having access to high-quality data and accomplishing economic growth and development. Indeed, human interactions have long been acknowledged as a critical aspect in overcoming organizational obstacles and achieving global growth and development. Human relations are crucial in the achievement of organizational goals, especially academic libraries around the world. Academic libraries in economically and socially viable countries are assisting in the transformation of their countries' economic and social well-being through effective and praiseworthy library services, with a focus on human relations.

It is anticipated that the availability of academic library materials be made known to members of the public or its user community, such as students and employees, who often comprise the greatest intellectual group or set of people with significant effect on social change and growth.

Information resources available at the library public relations services' departments and units are a collection of actions focused on putting people first in order to achieve organizational success. It has to do with networking as well

As long-term collaborations and partnerships which can emerge via networking; thus, allowing people and businesses to pool resources together in overcoming organizational difficulties (Dankowski, 2018). Libraries/librarians have a wealth of information to impart and are deeply rooted in their community services functions (Ewen, 2019).

According to Anonymous Publisher (2012), these characteristics of value to human relations officers, they frequently focus on the following "five top personal qualities/skills: communication skills (verbal and written), honesty/integrity, interpersonal skills (relates well to others), motivation/initiative, and strong work ethic" among others which not only allow but help organizations share information and achieve their goals. Thus, viable nations around the world pay attention to library information resources and services, leveraging information services through good human relations practices to foster learning/knowledge and strengthen their social economic architecture (Oyediran-Tidings, Onyenania \& Fadimu, 2019). Unfortunately, the situation in Nigeria does not appear to be the same.

As a result, there are several reports in the literature questioning the existence of COVID-19 in Nigeria and insincerity in the management of COVID-19 disseminated among many Nigerians. This situation could be linked to issues with human relations. To put it in another way, workplace attitude (human relations) appears to be lacking among librarians in academic libraries in recent times, particularly in developing countries like Nigeria; especially 


\section{Human Relations in Academic Libraries as Predictor in Managing the Spread of COVID-19 Pandemic for Sustainable Economic Development in Nigeria}

when considering the fact that libraries/librarians have a lot of knowledge to share and are so connected to their communities and people as expressed by Ewen (2019). This form of attitudinal functions and obligations could assist to slow the spread of COVID-19 across the country.

In other words, the study's main focus is on librarians' attitudes on customer service at work. In essence, the study predicts or is a predator in Managing the Spread of COVID-19 Pandemic for Sustainable Economic Development based on the type and style of human relations in academic libraries. Thus, in order to determine the level of perception, the study examines human connections in academic libraries as a predictor in managing the spread of the covid-19 epidemic for sustainable economic development in Nigeria, Nigerians' understanding of the existence and management of COVID-19, the level of librarians' human relations qualities toward the management of COVID-19's spread in Nigeria, the extent to which HR in academic libraries influences the management of COVID-19's spread in Nigeria towards sustainable economic development, as well as certain challenges confronting academic libraries in the management of COVID-19's spread; and to know if HR in academic libraries influences the management of COVID-19's spread in Nigeria towards sustainable economic development.

\section{Research Questions}

I. What is the current state of COVID-19 management in Nigeria's academic community?

II. How good are librarians' human relations skills when it comes to controlling the spread of COVID-19 in Nigeria? III. How has Human Relations in Academic Libraries influenced the management of COVID-19 spread in Nigeria in order to achieve long-term economic development?

IV. What are the obstacles faced by academic libraries in managing COVID-19's spread in Nigeria in order to achieve long-term economic development?

\section{LITERATURE REVIEW}

Several studies have previously predicted the importance of human relations in organizations and how they have aided in the achievement of organizational goals; and that people are an organization's most valuable asset. An organization's or institution's success is determined by the people it relates with, as well as how it mobilizes and motivates them. Organizations, like people oriented institutions, exist in a variety of shapes, sizes, and types. The library is one of these organizations where HR is necessary to achieve organizational objectives, particularly at a time when quality information is essential to curb the spread of COVID-19 in order to expand and sustain global economic growth and development.

Human relations are used to prepare for future organizational success as a result of interactions with the organization's internal and external communities (Dankowski, 2018). Close working relationships are formed via healthy social interactions with coworkers. In organizations, such working interactions translate into a dynamic and synergistic environment at the organizational reference desk, often known as 'tag-team reference'.

When two people work successfully or healthily together, they can bounce ideas off of one another and serve the organization's stakeholders, such as library patrons (users), in the most efficient way possible. Thus, it was stated that human relations (HR) encompasses actions relating to individuals, social groups, and organizations; and that HR is all about people, particularly those at work who make their workplaces function or productive as expected. People may make work environments fascinating, hilarious, and productive, or they can make them dull, ineffective as 
places where no one wants to go or participate. It's not about the ideas or the money that companies hold; it's about the people you have engaged/employed, how they're led, and how much you can get out of it. "It reflects on the development of creative products by recruiting the proper people for the job and cultivating a culture of hard work and innovation" says the author. Regardless of what you see on 24-hour news cycles, every individual in any society or nation genuinely wants to know what's going on and wants to use that information to improve their lives and support their communities in order to achieve the community's or nation's overall economic growth and development plan" (Ewen, 2019). Furthermore, it is no longer news that the deadly disease COVID-19, also known as the corona virus, welcomed the year 2020. According to various reports, the sickness has spread to every corner of the globe, and the current difficulty is that many people are skeptical about the virus's existence due to a lack of adequate information (Urhiewhu, Onyenania, \& Hassana, 2021). They also stated that even when adequate information is available, the majority of people lack health information literacy in general, and that without proper information, people's health information literacy about the virus is meaningless, which therefore calls for empirical evidence of this current study intents.

\section{RESEARCH METHODOLOGY}

A descriptive survey was used in this investigation. The study comprised library users of all categories (staff and students) from the University of Lagos (UNILAG), Yaba College of Technology (YABATECH), and FCE-Federal College of Education (Tech.) Akoka in Lagos State. Using the multivariate random sampling technique, Slovin's algorithm for sample size selection was utilized to select a sample size of 384 respondents. A questionnaire was used to collect information. The whole data received from 351 respondents ( 91.4 percent return rate) was analyzed using proper descriptive and inferential statistics to answer the study research questions and in testing a hypothesis at 0.05 significant level to arrive at the study conclusions.

\section{ANALYSIS OF DATA AND FINDINGS (RESULTS)}

Analysis of Data Relating to Research Question 1

Table 1: Perception of the level of the management of the spread of COVID-19 in academic community in Nigeria towards Sustainable Economic Development.

\begin{tabular}{|c|c|c|c|c|c|c|c|}
\hline Items/Statement & & $\begin{array}{l}\text { Very } \\
\text { Low } \\
\text { Extent }\end{array}$ & $\begin{array}{l}\text { Low } \\
\text { Extent }\end{array}$ & $\begin{array}{l}\text { High } \\
\text { Extent }\end{array}$ & $\begin{array}{l}\text { Very } \\
\text { High } \\
\text { Extent }\end{array}$ & Mean & Total \\
\hline $\begin{array}{l}\text { 1. My assessment of COVID-19 spread } \\
\text { prevention management in Nigeria through social } \\
\text { distancing measures in Nigeria is to the extent } \\
\text { specified. }\end{array}$ & $\begin{array}{l}\mathbf{f} \\
\%\end{array}$ & $\begin{array}{l}22 \\
6.4\end{array}$ & $\begin{array}{l}68 \\
19.5\end{array}$ & $\begin{array}{l}82 \\
23.5\end{array}$ & $\begin{array}{l}178 \\
50.6\end{array}$ & 2.412 & $\begin{array}{l}351 \\
100\end{array}$ \\
\hline $\begin{array}{l}\text { 2. COVID-19 spread prevention management in } \\
\text { Nigeria through regular hand washing measures } \\
\text { in running water as approved by NCDC in } \\
\text { Nigeria is to the specified extent. }\end{array}$ & $\begin{array}{l}\text { f } \\
\%\end{array}$ & $\begin{array}{l}35 \\
10.0\end{array}$ & $\begin{array}{l}75 \\
21.5\end{array}$ & $\begin{array}{l}130 \\
37.1\end{array}$ & $\begin{array}{l}110 \\
31.4\end{array}$ & 2.356 & $\begin{array}{l}351 \\
100\end{array}$ \\
\hline 3. COVID-19 spread prevention management in & $\mathbf{f}$ & 50 & 73 & 132 & 97 & 2.111 & 351 \\
\hline
\end{tabular}


Nigeria through regular hand sanitizer measures

$\begin{array}{ll}\% & 14.3\end{array}$

20.7

37.5

27.5

100

as approved by NCDC in Nigeria is to the

specified extent.

4. COVID-19 spread prevention management in f $\quad 27$

$\% 7.6$
77

178

19.9

21.9

50.6

2.214

351

Nigeria through regular use of face mask/shield measures as approved by NCDC in Nigeria is to the specified extent.

5. My assessment of COVID-19 management control/treatment measures and discharge of patients in Nigeria as approved by NCDC in Nigeria is to the specified extent.

6. My perception of the effectiveness of the gradual easing of lockdown measure resulting f $\quad 50$ 105 112 84 351 from COVID-19 pandemic as approved by $\% \quad 10.0$ $31.9 \quad 34.6$

NCDC in Nigeria is to the specified extent.

Cluster Mean / Overall Mean (2.323)

\section{Source: Field Survey 2020}

The descriptive analysis on the level of management of COVID-19 spread in Nigeria is shown in Table 1. Based on a cut-off point of 2.50 on a four-point Likert scale, the overall mean evaluation on the level of COVID-19 pandemic management in Nigeria is low (2.323). It expresses that the mean ratings of all items have been rejected. We would conclude that the level of management of COVID-19 spread in Nigeria is quite poor based on the cut-off point of 2.50 .

\section{Analysis of Data Relating to Research Question 2}

Table 2: Perception of the Level of Librarians Human Relations Qualities in the management of COVID-19 Pandemics in Nigeria towards Sustainable Economic Development.

\begin{tabular}{|c|c|c|c|c|c|c|c|}
\hline Items & & $\begin{array}{l}\text { Very } \\
\text { Low } \\
\text { Level }\end{array}$ & $\begin{array}{l}\text { Low } \\
\text { Level }\end{array}$ & $\begin{array}{l}\text { High } \\
\text { Level }\end{array}$ & $\begin{array}{l}\text { Very } \\
\text { Low } \\
\text { Level }\end{array}$ & Mean & Total \\
\hline $\begin{array}{l}\text { 1. Librarian's approach-ability quality helps in } \\
\text { accessing required information in libraries } \\
\text { towards the management of the spread of COVID- } \\
19 \text { in Nigeria }\end{array}$ & $\begin{array}{l}\text { f } \\
\%\end{array}$ & $\begin{array}{l}43 \\
7.2\end{array}$ & $\begin{array}{l}96 \\
28.3\end{array}$ & $\begin{array}{l}108 \\
33.1\end{array}$ & $\begin{array}{l}104 \\
31.5\end{array}$ & 2.310 & $\begin{array}{l}351 \\
100\end{array}$ \\
\hline $\begin{array}{l}\text { 2. Librarian's politeness quality helps in accessing } \\
\text { and use of required information in libraries } \\
\text { towards the management of COVID-19 in Nigeria }\end{array}$ & $\begin{array}{l}\text { f } \\
\%\end{array}$ & $\begin{array}{l}48 \\
9.2\end{array}$ & $\begin{array}{l}111 \\
34.3\end{array}$ & $\begin{array}{l}113 \\
35.0\end{array}$ & $\begin{array}{l}79 \\
21.5\end{array}$ & 2.432 & $\begin{array}{l}351 \\
100\end{array}$ \\
\hline 3. Librarians good communication skills help in & $\mathbf{f}$ & 42 & 110 & 106 & 93 & 2.478 & 351 \\
\hline
\end{tabular}


the use of required information in libraries $\begin{array}{llll}\% & 6.8 & 33.9 & 32.3\end{array}$

towards the management of the spread of COVID-

19 in Nigeria

4. Librarian's friendliness quality helps in the access and use of required information in libraries f $53 \quad 70 \quad 110$

118 towards the management of the spread of COVID-

19 in Nigeria

5. Librarians good ethical conducts helps in the f $\quad 80 \quad 80 \quad 81$ use of required information in libraries towards \% 21.9

the management of the spread of COVID-19 in Nigeria

6. Librarians love of knowledge helps in the access and use of required information in libraries

f $\quad 40 \quad 105 \quad 86$
towards the management of the spread of COVID-

19 in Nigeria

7. Librarians unbiases quality enhances the use of f $42 \quad 113 \quad 85$ management of the spread of COVID-19 in Nigeria.

\section{Cluster Mean / Overall Mean (2.333)}

\section{Source: Field Survey 2020}

The descriptive analysis of the Level of Librarians Human Relations Qualities in the Management of COVID-19 Pandemics in Nigeria for Sustainable Economic Development is shown in Table 2. When considering the overall mean rating value of 2.333 on table 3 and the criteria mean value placement at 2.50 (cut-off point) based on the four Likert scaling types used in the study, the overall mean rating on the level of Librarians Human Relations Qualities in the management of the COVID-19 pandemic shows it is low. As a result, we can say that the perception of Librarians' Human Relations Qualities in the Management of COVID-19 Pandemics in Nigeria for Sustainable Economic Development is quite low.

\section{Analysis of Data Relating to Research Question 3}

Table 3: Perception of the Extent of Human Relations in Academic Libraries Influence on the Management of the Spread of COVID-19 in Nigeria towards Sustainable Economic Development.

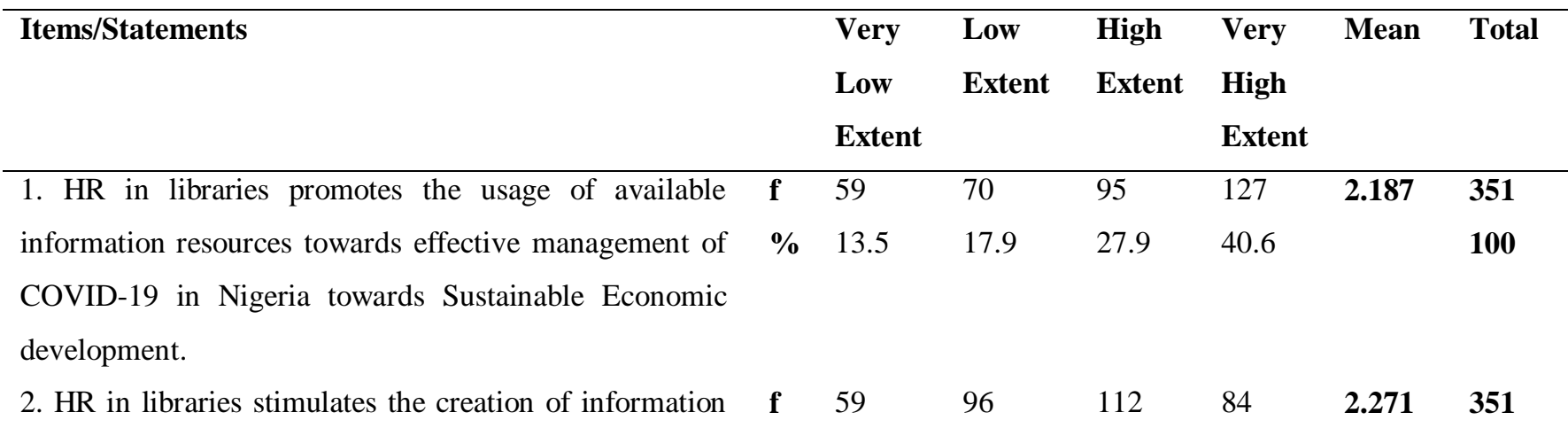


Human Relations in Academic Libraries as Predictor in Managing the Spread of COVID-19

Pandemic for Sustainable Economic Development in Nigeria

resources towards effective COVID-19 preventive

$\begin{array}{lllll}\% & 13.5 & 28.3 & 34.7 & 23.5\end{array}$

100

measures approved by NCDC in Nigeria towards

Sustainable Economic development

3. HR in libraries helps to sustain the advocacy of COVID-19 preventive measures approved by NCDC in

f 68

$\% \quad 17.1$

82

111

90

2.234

351

Nigeria towards Sustainable Economic development.

4. HR in libraries enhances quality access to information f 54 92

121

84

2.149

351

resources to support COVID-19 management in Nigeria

$\% \quad 11.6$

26.7

38.2

23.5

100

towards Sustainable Economic development.

5. HR in libraries helps to discourage COVID-19 f 53 107

115

$$
76
$$

351 disbelieve among Nigerians

$\% \quad 11.2$

35.9

20.3

6. HR in libraries enhances quality access to information

f 58

96

98

99

2.447

100

resources to support COVID-19 management in Nigeria

$\% \quad 13.1$

28.3

29.1

29.5

351

towards Sustainable Economic development.

7. HR in libraries influences health literacy information use relating to the management of the spread of COVIDf $\quad 57$ 105 101 88

19 toward sustainable economic development in Nigeria.

$\% \quad 12.7$

8. HR in libraries helps to discourage COVID-19 flying rumors capable of having adverse effect on the sustainable economic development.

\section{Cluster Mean / Overall Mean (2.307)}

\section{Source: Field Survey 2020}

The descriptive study on the Perception of the Extent of Human Relations in Academic Libraries Influence on the Management of COVID-19 Spread in Nigeria for Sustainable Economic Development is shown in Table 3.

When evaluating the overall mean rating value of (2.307) on table 4 and the study criterion mean value of 2.50 , the overall mean rating on the Perception of the Extent of Human Relations in Academic Libraries Influence on the Management of the Spread of COVID-19 pandemic demonstrates it is low (cut-off point). We can conclude that the influence of perceptions of the extent of human relations in academic libraries on the management of COVID-19 spread in Nigeria for sustainable economic development is minimal.

\section{Analysis of Data Relating to Research Question 4}

Table 4: Factors Confronting Academic Libraries in the Management of the Spread of COVID-19 in Nigeria

\begin{tabular}{lllllllll}
\hline S/N & Items & & SA & A & D & SD & Mean & Total \\
\hline 1 & Low level of human relations practices in libraries & $\mathbf{f}$ & 132 & 97 & 50 & 73 & $\mathbf{2 . 9 7 1}$ & $\mathbf{3 5 1}$ \\
& & $\mathbf{\%}$ & 37.5 & 27.5 & 14.3 & 20.7 & $\mathbf{1 0 0}$ & \\
2 & Poor publicity of information resources relating to & $\mathbf{f}$ & 101 & 116 & 48 & 86 & $\mathbf{2 . 5 8 7}$ & $\mathbf{3 5 1}$ \\
& COVID-19 management. & $\mathbf{\%} 30.2$ & 36.3 & 9.2 & 24.3 & $\mathbf{1 0 0}$
\end{tabular}


Poor Internet connectivity problems in libraries.

f $110 \quad 106 \quad 93 \quad 42$

2.834

351

$\begin{array}{lllll}\% & 33.9 & 32.3 & 27.1 & 6.8\end{array}$

100

Access time in most cases is restricted (Insufficient

f $\quad 110$

118

$53 \quad 70$

access time) resulting from poor network and power

$\begin{array}{lllll}\% & 33.9 & 37.0 & 11.2 & 17.9\end{array}$
supply in libraries.

I am not competent in accessing library resources that

f $\quad 108 \quad 114 \quad 58 \quad 71$

would enhance my understanding of the existence of

$\begin{array}{lllll}\% & 33.0 & 35.5 & 13.1 & 18.3\end{array}$
COVID-19 in Nigeria.

Many Nigerians disbelief the existence of COVID-19

f 110
because of lack of proper information

\% 33.8

117

60

Unreliable/Irregular Subscription to available Databases

f $\quad 114 \quad 148 \quad 39 \quad 50$
relating to COVID-19 Data/information due to

Poor/inadequate Funding

Poor/inadequate human

advertising/promoting available information resources

f 105

$112 \quad 50 \quad 84$

that could enhance COVID-19 understanding and

$\begin{array}{lllll}\% & 31.9 & 34.6 & 10.0 & 23.5\end{array}$

management among Nigerians by librarians.

10 Poor health information literacy about the COVID-19 virus among Nigerians

$\begin{array}{lll}101 & 88 & 57\end{array}$

11 Poor Library development leading to inadequate

$11145 \quad 9$

COVID-19 related information services

$\begin{array}{lllll}\text { \% } & 53.2 & 31.5 & 12.8 & 2.5\end{array}$

I am not aware of the existence of information resources

f $107 \quad 115 \quad 76 \quad 53$
that support the understanding the existence and $\begin{array}{llll}\% & 32.7 & 35.9 & 20.3\end{array}$ management of the spread of COVID-19 in libraries.

13 I encounter low level of support from library personnel

$\begin{array}{lllll}\text { f } & 77 & 178 & 27 & 70 \\ \text { \% } & 21.9 & 50.6 & 7.6 & 19.9\end{array}$

(s) due to poor human relations problems in libraries

(Poor library staff and user's relationship)

\section{Cluster Mean / Overall Mean (2.871)}

\section{Source: Field Survey 2020}

The descriptive analysis on Factors Confronting Academic Libraries in the Management of COVID-19 Spread in Nigeria is shown in Table 4. When evaluating the total mean rating value of 2.871 on table 5 and the study criterion mean value of 2.50, the overall mean rating on Factors Confronting Academic Libraries Management of the Spread of COVID-19 pandemic demonstrates they are very many or very high (cut-off point). According to the findings, health information literacy concerning the COVID-19 virus is low in Nigerian university institutions, and library development is lacking, resulting in insufficient COVID-19-related information services at higher institutions. We find that the challenges academic libraries face in managing the spread of COVID-19 in Nigeria is numerous. 


\section{Human Relations in Academic Libraries as Predictor in Managing the Spread of COVID-19 Pandemic for Sustainable Economic Development in Nigeria}

\section{FINDINGS}

Generally, the study discovered that the level of management of COVID-19 pandemics in Nigeria is low, and that the perception of the Level of Librarians Human Relations Qualities exhibited toward the management of COVID19 Pandemics in Nigeria for Sustainable Economic Development is also very low. As a result, the study discovered that the extent to which Human Relations in academic libraries influences the management of COVID-19 spread in Nigeria towards sustainable economic development is very low, and that academic libraries face numerous challenges or factors in managing COVID-19 spread in Nigeria.

\section{CONCLUSION AND RECOMMENDATIONS}

In light of the aforementioned, the study concluded that COVID-19, like every other pandemic in history, is here to stay. Because most information coming from libraries is usually free of doubt, the human relations (HR) concept is an important variable in library services that could bring about a change in attitude toward the use of library resources among users, especially towards improving understanding of the existence of COVID-19 among Nigerians. Such HR practices in libraries would aid in the successful management of the fatal virus's spread in the country, as well as the country's long-term economic prosperity.

The study therefore recommends that management should take human relations issues in academic libraries seriously in order to improve information services to users and facilitate a shift in attitude/understanding towards the "win, win, notion" fight against the COVID-19 pandemic, among other things, in order to achieve the country's long-term economic development.

\section{REFERENCES}

[1] Anonymous Publisher (2012). Human relations: BA107. Retrieved October 15, 2021 from: www.http://2012books.lardbucket.org.

[2] Dankowski, T. (2018). 11 Tips for Meaningful Networking: Library pros share advice for meeting people and sustaining relationships. American Libraries Magazine, November/December 2018, 42-43. Retrieved October 12, 2021 from: www.http.//americanlibrariesmagazine.org

[3] Ewen, L. (2019). Connecting with Congress: How libraries can build relationships with elected officials through year-round advocacy. American Magazine, November/December 2019, 26-29. Retrieved October 10, 2020 from Americanlibrariesmagazine.org.

[4] Giraldo, A. (2019). Sustainability and 5 Examples of Economic Growth. Retrieved September 10,2020 from: https://ideasforus.org/sustainability-and-5-examples-of-how-it-helps-conomic-growth/

[5] Okemakinde, T. (2014). Women education: Implications for national development in Nigeria. European Journal of Globalization and Development Research, 9 (1), 533- 565.

[6] Oyediran-Tidings, S. O., Onyenania, G. O. \& Fadimu, A. A. (2019). Access to Library Online Resources and Services as Requisite for Learning and Security Information: Study of Selected Higher Institutions in Lagos State, Nigeria. A Paper Presented at the Yaba College of Technology ASUP $2^{\text {nd }}$ International Conference Held at the Multipurpose Hall, Yaba College of Technology, Lagos, from $18^{\text {th }}-19^{\text {th }}$ September, 2019.

[7] Sahu, A K. (2007). Measuring service quality in an academic library: an Indian case study. Library Review, 56 (3), 234-243.

[8] Urhiewhu, L. O., Hassana, D. A. \& Onyenania, G.O. (2021). Addressing health information literacy in Era of COVID 19 pandemic: The role of the Health Librarian in Nigeria. Ondo City: UNIMED Press. 